\title{
ISOENZYME PATTERNS OF SEVERAL HYDROLYTIC ENZYMES OF AGROBACTERIUM TUMEFACIENS
}

\author{
PIJUSH K. DAS, MITALI BASU, AND GORA C. CHATTERJEE \\ Department of Biochemistry, University of Calcutta, \\ Calcutta-700019
}

(Received October 24, 1977)

\begin{abstract}
The isoenzyme patterns of several hydrolytic enzymes, viz., acid phosphatase, alkaline phosphatase, and catalase, in virulent and avirulent, agrocin-resistant Agrobacterium tumefaciens have been studied. Agrocin resistance brought about genetic repression in regard to the synthesis of one of the isoenzymes in each of these three enzymes. Avirulent resistant strains also showed a reduction in the activities of all the hydrolases. Although $\mathrm{Mg}^{2+}$ stimulated the activity of alkaline phosphatase, no absolute requirement of any metal ions for the activity of the enzyme was observed.
\end{abstract}

Certain strains of phytopathogenic bacterium, Agrobacterium tumefaciens, which are sensitive to agrocin (a bacteriocin produced by $A$. radiobacter), lose their plasmids with subsequent loss in their crown gall-inducing potency in plants and also as a result they develop resistance towards agrocin $(1,2)$. Certain resistant strains are also developed which do not lose plasmids but are incapable of inducing crown gall tumor formation (2). Recently several reports are available regarding the appearance of a number of isoenzymes in plant crown gall tumor cells which are infected by Agrobacterium tumefaciens $(3,4)$. Although the possibility exists that some of these enzymes may be of bacterial origin, there is equal probability that they occur merely as a result of the expression of normal genes which are transcribed only at certain stages of growth in normal cells but remain expressed in crown gall cells, or that they are simply normal products modified in crown gall cells. To ascertain the exact mechanism which is operating in crown gall cells and also to know the mode of action of agrocin in relation to crown gall-inducing potency, it is thought worthwhile to study the isoenzyme pattern of some hydrolytic enzymes viz., alkaline phosphatase, acid phosphatase, and catalase, in the above-mentioned virulent and avirulent strains of Agrobacterium tumefaciens, using polyacrylamide gel electrophoresis. 


\section{MATERIALS AND METHODS}

Chemicals. Thiamine pyrophosphate was obtained from Nutritional Biochemicals Corporation, U.S.A., and sodium $\beta$-glycerophosphate was a product of Koch-Light Laboratories Ltd., England. $p$-Nitrophenyl phosphate, adenosine monophosphate, Fast Blue RR, 1-naphthyl phosphate, and poly(vinylpyrrolidone) were purchased from Sigma Chemical Co., U.S.A. Sodium pyrophosphate was obtained from E. Merck and Co., West Germany.

Test organism and growth medium. Strains used in this investigation are A. tumefaciens TIP (Kerr 14) agrocin-sensitive, A. tumefaciens TIP (Kerr 14) R, agrocin-resistant and probably completely cured of plasmid, and $A$. tumefaciens S1005, agrocin-resistant variety. Cultures of all these $A$. tumefaciens strains have been obtained from Prof. J. Schell, Director, Laboratorium voor Genetica, Rijks Universiteit, Gent, Belgium. For comparative purposes, strains of $A$. tumefaciens with a maximal growth temperature of $28^{\circ}$ were employed. The growth medium consisted of $0.8 \%$ Bactotryptone, $0.5 \%$ Bactoyeast extract, and $0.5 \% \mathrm{NaCl}$ in distilled water. The stock cultures were maintained on agar slants of the same medium.

Enzyme assays. For the assay of alkaline phosphatase the cells of mid log phase were suspended in $0.03 \mathrm{M}$ Tris- $\mathrm{HCl}$ buffer, $\mathrm{pH} 7.8$, after harvesting and washing with the same buffer. The cells were then subjected to butanol extraction according to the method described by $\operatorname{BHATti}(5,6)$. Alkaline phosphatase $(p$ nitrophenyl phosphatase) activity was determined following the method of MrTCHELl et al. (7). The activity of other alkaline phosphatases, viz., $\beta$-glycerophosphatase, adenosinemonophosphatase, thiamine pyrophosphatase, and sodium pyrophosphatase, was determined on the basis of released inorganic phosphate measurement after the method of LOWRY and LOPEZ (8).

Cell-free extracts for the determination of catalase were prepared according to the following procedure: Cells of mid log phase were harvested by centrifugation and washed with $0.01 \mathrm{M}$ phosphate buffer, $\mathrm{pH} 7.8$. The washed cells were frozen overnight at $-18^{\circ}$. Cells were then disrupted by sonication in a Raytheon Sonic Oscillator $(10,000 \mathrm{kHz}$, two 30 -sec exposures) and were centrifuged at $20,000 \times g$ for $20 \mathrm{~min}$ to remove the cell debris and unbroken cells. The supernatants were used as enzyme sources. Catalase was assayed according to the method of SinHA (9). Cell-free extracts of acid phosphatase determination were prepared as for the catalase assay, with the only modification that the cells were washed with and suspended in $0.03 \mathrm{M}$ Tris- $\mathrm{HCl}$ buffer, $\mathrm{pH}$ 7.4. Acid phosphatase activity was measured after the method of MitCHELL et al. (7) using $p$-nitrophenyl phosphate as a substrate. The enzyme activity using other substrates, viz., $\beta$-glycerophosphate, sodium pyrophosphate, thiamine pyrophosphate, etc., was determined by the method of LOWRY and Lopez (8). Protein was estimated by the method of LOWRY et al. (10) with crystalline bovine serum albumin as standard. All spectrophotometric measurements of enzyme activity were made with a Beckman DU-2 
spectrophotometer. The specific activity of the enzymes, viz., acid phosphatase and alkaline phosphatase, is defined as $\mu \mathrm{g}$ of $p$-nitrophenol liberated per minute per mg of protein.

Study of isoenzymes using polyacrylamide gel electrophoresis. Polyacrylamide gels were prepared according to the procedure of DAvIs (11). The isoenzyme pattern of alkaline phosphatase and acid phosphatase in agrocin-sensitive and agrocin-resistant strains was studied on $7.5 \%$ polyacrylamide gels with $0.004 \mathrm{M}$ histidine buffer, $\mathrm{pH} 7.0$, as gel buffer and $0.041 \mathrm{~m}$ sodium citrate, $\mathrm{pH} 7.0$, as bridge buffer (12). A current of $3 \mathrm{~mA}$ per tube was applied for $3 \mathrm{hr}$. After electrophoresis, the gels were briefly washed with water and incubated for $2 \mathrm{hr}$ at $37^{\circ}$ in a staining mixture described by BREWER (13). After staining, the gels were stored in $50 \%$ ethanol. The isoenzyme patterns of catalase in virulent and avirulent strains were studied on $5 \%$ polyacrylamide gels with Tris $(1.5 \mathrm{M})-\mathrm{HCl}(0.24 \mathrm{M})$ containing $\mathrm{N}, \mathrm{N}, \mathrm{N}^{\prime}, \mathrm{N}^{\prime}$-tetramethylethylenediamine $(27 \mathrm{mM})$ as gel buffer and $5 \mathrm{~mm}$ Tris-48 mm glycine, $\mathrm{pH} 8.3$, as bridge buffer. The electrophoresis was carried out for $4 \mathrm{hr}$ using a current of $2.5 \mathrm{~mA}$ per tube. The gels were stained for catalase activity according to the method of WoODBERG et al. (14) using $0.003 \% \mathrm{H}_{2} \mathrm{O}_{2}, 2 \%$ $\mathrm{FeCl}_{3}$, and $2 \% \mathrm{~K}_{3}(\mathrm{FeCN})_{6}$.

\section{RESULTS}

Table 1 shows the activity of alkaline phosphatase and acid phosphatase using different substrates in sensitive and agrocin-tolerant mutants of A. tumefaciens. All the three strains possess less $\beta$-glycerophosphatase, adenosinemonophosphatase, thiamine pyrophosphatase, and sodium pyrophosphatase activity than the $p$-nitrophenyl phosphatase activity. The specific activity of acid phosphatase is much lower than that of alkaline phosphatase in all the strains. It is also observed that the activity of all the substrate-specific phosphatases in both acid and alkaline $\mathrm{pH}$ are decreased in agrocin-resistant strains of $A$. tumefaciens.

Table 2 shows the effect of addition of metal ions on the alkaline phosphatase activity in normal and resistant strains. The addition of $\mathrm{Mg}^{2+}$ stimulates the activity of alkaline phosphatase whereas $\mathrm{Zn}^{2+}$ has more or less no effect on the activity. The addition of $\mathrm{Mn}^{2+}$ and $\mathrm{Co}^{2+}$ drastically inhibits the alkaline phosphatase activity.

Figure 1 shows the catalase activity of both intact cells and cell-free extracts of all the three strains of $A$. tumefaciens. It is observed that the activity in the virulent strain is high enough from the start of the experiment and it steadily increases with time, whereas in the case of avirulent resistant strains, the activity is lower than that in the normal strain.

The isoenzymatic patterns of alkaline phosphatase, acid phosphatase, and catalase obtained by polyacrylamide gel electrophoresis are shown in Figs. 2, 3, and 4, respectively. The normal virulent strain possesses two alkaline phosphatase 


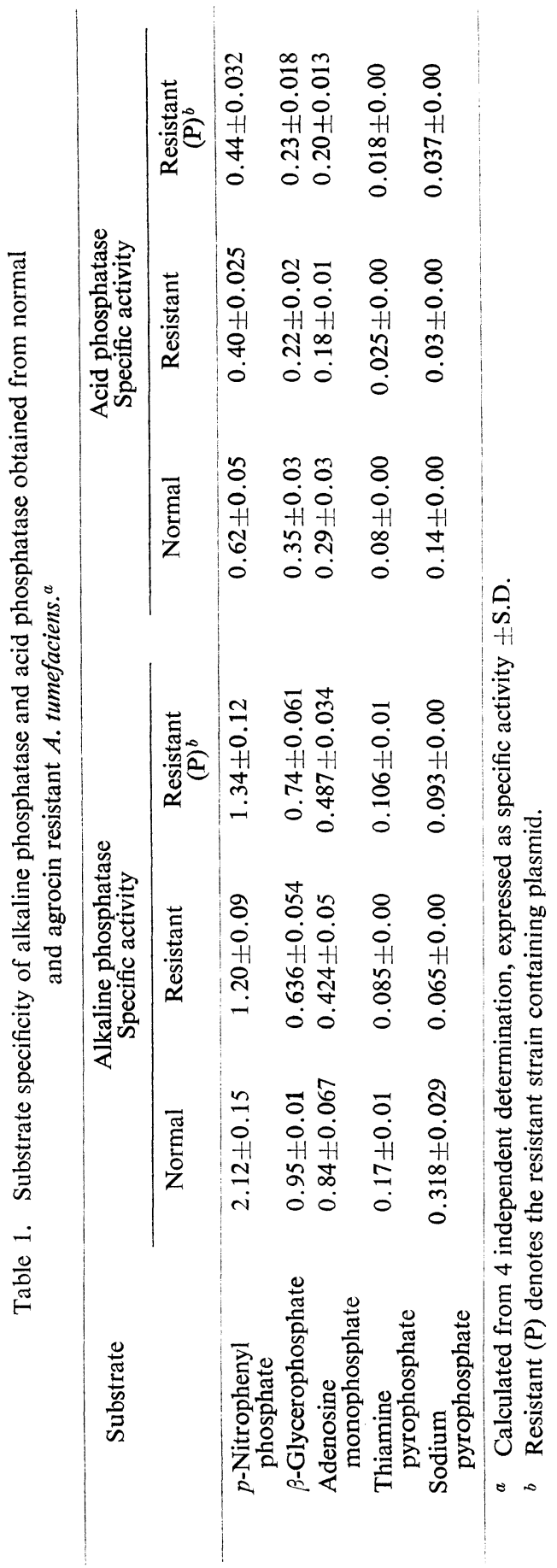


Table 2. Effect of $\mathrm{Mg}^{2+}, \mathrm{Zn}^{2+}, \mathrm{Mn}^{2+}$, and $\mathrm{Co}^{2+}$ on the activity of alkaline phosphatase in normal and agrocin resistant $A$. tumefaciens.

\begin{tabular}{|c|c|c|c|c|c|}
\hline \multirow{2}{*}{ No. } & \multirow{2}{*}{$\begin{array}{l}\text { Metal ions } \\
\text { added }\end{array}$} & \multirow{2}{*}{$\begin{array}{c}\text { Final } \\
\text { concentration } \\
\text { (mM) }\end{array}$} & \multicolumn{3}{|c|}{ Specific activity of enzyme in } \\
\hline & & & Normal & Resistant & Resistant $(\mathrm{P})^{a}$ \\
\hline \multirow{3}{*}{1} & \multirow{3}{*}{$\mathrm{Mg}^{2+}$} & Nil & 2.24 & 1.10 & 1.50 \\
\hline & & 5 & 2.80 & 1.76 & 1.95 \\
\hline & & 10 & 3.52 & 2.16 & 2.45 \\
\hline \multirow{3}{*}{2} & \multirow{3}{*}{$\mathrm{Zn}^{2+}$} & Nil & 2.12 & 1.20 & 1.34 \\
\hline & & 5 & 1.82 & 0.91 & 1.05 \\
\hline & & 10 & 1.93 & 0.95 & 1.07 \\
\hline \multirow{3}{*}{3} & \multirow{3}{*}{$\mathrm{Mn}^{2+}$} & Nil & 2.12 & 1.20 & 1.34 \\
\hline & & 5 & 0.48 & 0.24 & 0.33 \\
\hline & & 10 & 0.30 & 0.14 & 0.19 \\
\hline \multirow{3}{*}{4} & \multirow{3}{*}{$\mathrm{CO}^{2+}$} & Nil & 2.00 & 1.10 & 1.20 \\
\hline & & 5 & 0.61 & 0.43 & 0.35 \\
\hline & & 10 & 0.39 & 0.17 & 0.13 \\
\hline
\end{tabular}

a Resistant (P) denotes the resistant strain containing plasmid.

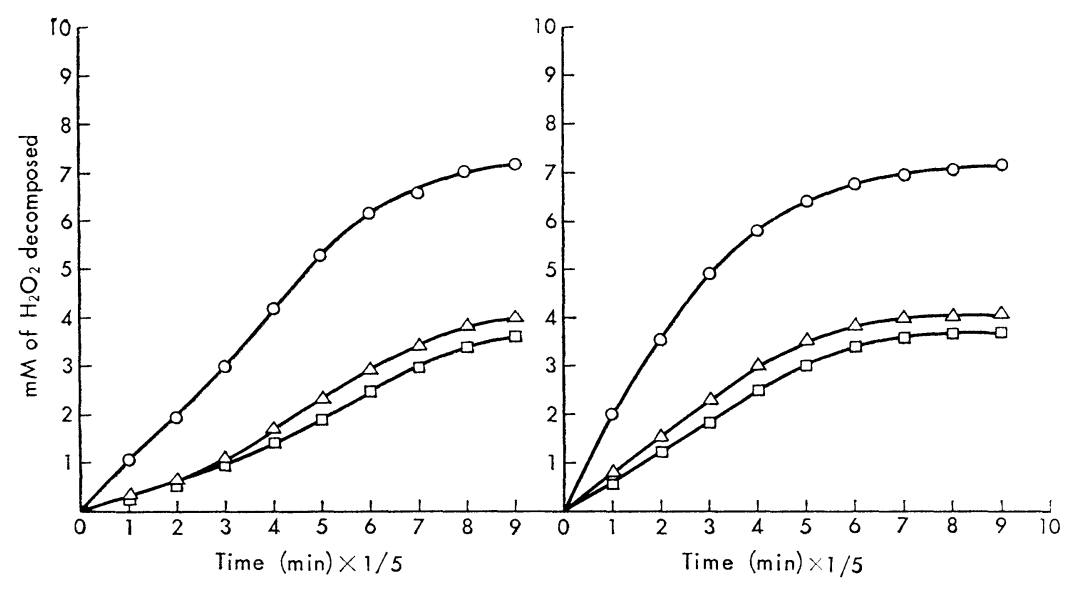

(A) Intact cells

(B) Cell-free extract.

Fig. 1. Activity of catalase in normal and agrocin-resistant $A$. tumefaciens. $\bigcirc$, normal; $\triangle$, resistant; $\square$, resistant containing plasmid.

isoenzymes; one is an intense major band and the other is a light minor band. Both the avirulent resistant strains have only one alkaline phosphatase corresponding to the intense major band of the normal strain. It is noted from Figs. 3 and 4 that there are three isoenzymes of either acid phosphatase or catalase in the virulent strain whereas the avirulent resistant strains contain two acid phosphatase and catalase isoenzymes. The three isoenzymes of catalase in the virulent strain are represented by a major band and two minor bands. In the case of avirulent resistant strains the lowermost minor band is absent. 


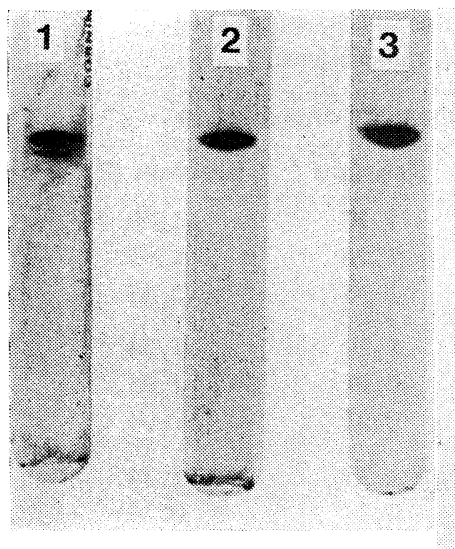

Fig. 2.

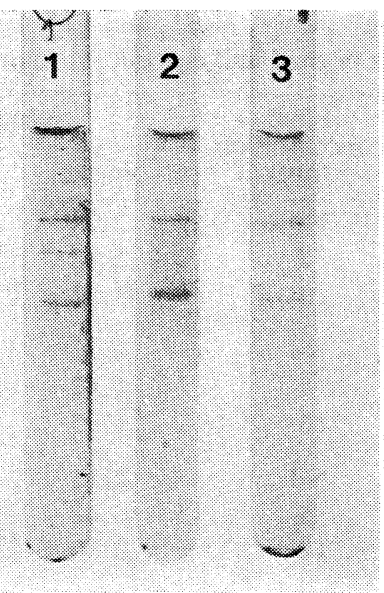

Fig. 3.

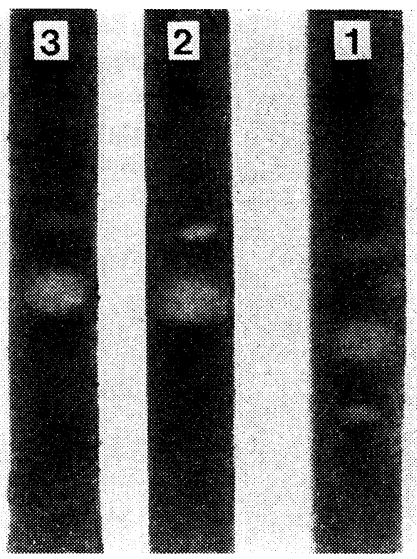

Fig. 4.

Fig. 2. Isoenzyme pattern of the enzyme alkaline phosphatase in A. tumefaciens. 1 , normal; 2 , resistant; 3 , resistant containing plasmid.

Fig. 3. Isoenzyme pattern of the enzyme acid phosphatase in A. tumefaciens. 1 , normal; 2 , resistant; 3 , resistant containing plasmid.

Fig. 4. Isoenzyme pattern of the enzyme catalase in A. tumefaciens 1 , normal; 2 , resistant; 3 , resistant containing plasmid.

\section{DISCUSSION}

A. tumefaciens phosphatases are non-specific phosphohydrolases, as both of them have been found to hydrolyze $p$-nitrophenyl phosphate, $\beta$-glycerophosphate, thiamine pyrophosphate, adenosine monophosphate, and sodium pyrophosphate. However, the specific activity of acid phosphatase is much lower than that of alkaline phosphatase in A. tumefaciens. Alkaline phosphatase from normal and agrocin-resistant $A$. tumefaciens is inhibited by $\mathrm{Mn}^{2+}$ and $\mathrm{Co}^{2+}$ but is not affected by $\mathrm{Zn}^{2+}$ or EDTA. Though the enzyme from both the normal and resistant strains is stimulated by $\mathrm{Mg}^{2+}$, still there is activity of the enzyme without the addition of any metal ion which suggests that it does not have an absolute requirement for metal ions. The E. coli alkaline phosphatase requires $\mathrm{Zn}^{2+}$ for full expression of its activity $(15,16)$ while in the case of $N$. crassa the enzyme is unaffected by the presence of metal ions (17). The observations further indicate that both acid phosphatase and alkaline phosphatase activities are decreased in agrocin-resistant strains of $A$. tumefaciens. Such a decrease in alkaline phosphatase activity in streptomycin-resistant bacteria has been reported by LoKIEWIEZ et al. (18) and by Rosenkranz et al. (19). That the activities of both phosphatases are decreased in agrocin-resistant strain is also obvious from Figs. 2 and 3 which show a reduction of one isoenzyme each of both acid and alkaline phosphatase in the case of avirulent resistant strains. This indicates that the agrocin resistance brings about genetic repression in regard to the synthesis of one isoenzyme in $A$. tumefaciens. 
It is observed from Fig. 1 that the catalase activity of both intact cells and cell-free extract in the normal strain steadily increases with time and the reaction proceeds to completion with increasing time whereas that in the resistant strains the activity is lower than that of the normal. A decrease of catalase activity was also observed in the mutants of $K$. pneumoniae resistant to streptomycin (20). The above observation that the catalase activity is decreased in agrocin-resistant strains is in accordance with the polyacrylamide gel electrophoretic patterns of the enzyme catalase obtained from virulent and avirulent strains of $A$. tumefaciens (Fig. 4). The isoenzyme pattern of catalase obtained from normal cells shows that it has three isoenzymes represented by a major band and two minor bands. In the case of resistant strains, the lowermost minor band is eliminated and thus the number has been reduced to two. Here also the development of resistance towards agrocin brings about an alteration in relation to the genetic formation of catalase isoenzyme. Therefore, it may be suggested from this investigation that at least some of the new isoenzymes which were found to appear in plant crown gall tumor cells when infected with $A$. tumefaciens $(3,4)$ are of bacterial origin, since the normal agrocin-sensitive $A$. tumefaciens which are capable of inducing crown gall tumor formation have been found to possess higher number of isoenzymes than that in the agrocin-resistant strains of $A$. tumefaciens which are incapable of inducing crown gall tumor formation.

Thanks are due to the University Grants Commission, India, for financing the project.

\section{REFERENCES}

1) A. Kerr and K. Htay, Physiol. Plant Pathol., 4, 37 (1974).

2) J. Schell, In Genetic Manipulations with Plant Materials, ed. by L. Ledoux, Plenum Press, New York (1975), p. 163.

3) M. N. Reddy and M. A. Stahmann, Phytopathol. Z., 78, 301 (1973).

4) C. R. Curtis, Can. J. Bot., 49, 333 (1971).

5) A. R. BHATtI, Arch. Microbiol., 95, 255 (1974).

6) A. R. BнAтtI, FEBS Lett., 32, 81 (1973).

7) R. M. Mitchell, M. J. Karnovosky, and M. L. Karnovosky, Biochem. J., 116, 207 (1970).

8) O. H. Lowry and J. A. LopeZ, J. Biol. Chem., 162, 421 (1946).

9) A. K. SinHA, Anal. Biochem., 47, 389 (1972).

10) O. H. Lowry, N. J. Rosebrough, A. L. Farr, and R. J. Randall, J. Biol. Chem., 193, 265 (1951).

11) B. J. Davis, Ann. N. Y. Acad. Sci., 121, 404 (1964).

12) S. H. BOYER, Science, 134, 1002 (1961).

13) G. J. BREwER and C. F. Sing, An introduction to Isoenzyme Techniques, p. 92, (1970), Academic Press, New York.

14) W. Woodberg, A. K. Spencer, and M. A. Stahmann, Anal. Biochem., 44, 301 (1971).

$15)$ D. J. Plocke, C. Levinthal, and B. L. Vallee, Biochemistry, 1, 373 (1962).

16) F. Rothman and R. J. Byrne, J., Mol. Biol., 6, 330 (1963).

17) R. J. KadNer and J. F. NYC, J. Biol. Chem., 244, 5125 (1969).

18) Z. Lokiewiez, I. Zelazna, and B. Przybojewska, Acta Microbiol. Pol., 14, 225 (1965).

19) H. S. Rosenkranz, A. J. Bendich, and H. S. CARr, Biochim. Biophys. Acta., 82, 110 (1964).

20) N. M. KRANSNYTSKa, Microbiol. Zh. (Kiev), 35, 739 (1973). 